\title{
Penerapan Metode Topsis pada Sistem Pendukung Keputusan untuk Kota yang Menerapkan Pembatasan Sosial Berskala Besar yang di Sebabkan Wabah Corona
}

\author{
Fawwaz Ramzy Darmawan ${ }^{1}$, Eka Larasati Amalia ${ }^{2}$, Ulla Defana Rosiani ${ }^{3}$ \\ Program Studi Teknik Informatika, Jurusan Teknologi Informasi, Politeknik Negeri Malang \\ Jl. Soekarno Hatta No.9, Jatimulyo, Kec. Lowokwaru, Kota Malang, Jawa Timur 65141 \\ 11741720067 epolinema.ac.id \\ eka.larasati@polinema.ac.id \\ ${ }^{3}$ rosiani@polinema.ac.id
}

\begin{abstract}
Abstrak
Pembatasan Sosial Berskala Besar istilah kekarantinaan kesehatan di Indonesia yang diartikan sebagai Pembatasan kegiatan tertentu oleh sebagian besar penduduk pada suatu wilayah. Perhitungan yang akurat merupakan suatu kewajiban sehingga menghasilkan suatu keputusan yang tepat. Pada penelitian ini dibuat suatu Sistem Pendukung Keputusan untuk membantu suatu pihak pengambil keputusan dalam penentuan penerapan Pembatasan Sosial Berskala Besar. Sistem Pendukung Keputusan (SPK) merupakan suatu sistem berbasis komputer yang menghasilkan berbagai alternatif keputusan untuk membantu pihak pengambil keputusan. Sistem pendukung keputusan bukan merupakan alat pengambilan keputusan, melainkan sebagai sistem yang membantu pengambil keputusan yang dilengkapi informasi dari data yang telah diolah dengan relevan dan hasil yang mempunyai ke akuratan yang tinggi. Program yang dibuat merupakan program yang berbasis web, dan metode Topsis merupakan metode yang digunakan pada aplikasi ini. Metode Topsis adalah salah satu metode pengambilan keputusan multikriteria yang memiliki jarak terpendek dari solusi ideal positif dan jarak terjauh dari solusi ideal negatif.
\end{abstract}

\section{Implementation of Topsis Method in Decision Support System for Cities Implementing Large-Scale Social Restrictions Caused by Corona}

\begin{abstract}
Large-scale Social Restrictions on health quarantine in Indonesia is defined as the Restriction of certain activities by the majority of the population in a region. Accurate calculation is an obligation to make the right decision. In this research, a Decision Support System was created to assist a decision-making party in determining the implementation of Large-Scale Social Restrictions. A Decision Support System (SPK) is a computer-based system that produces various alternative decisions to help decision-makers. A decision support system is not a decision-making tool, but rather a system that helps decision-makers who are equipped with information from data that has been processed with relevant and results that have high accuracy. The program created is a web-based program, and the Topsis method is the method used in this application. The Topsis method is one of the multicritical decision-making methods that has the shortest distance from the ideal positive solution and the furthest distance from the negative ideal solution.
\end{abstract}

Keywords: SPK, Topsis, Decision Support System, PSBB

\section{Pendahuluan}

PSBB sebuah ketentuan tentang pembatasan melakukan interaksi sosial dengan bebas. Aturan PSBB tercatat dalam Peraturan Menteri Kesehatan Nomor 9 Tahun 2020. Untuk mendukung berlangsungnya PSBB, maka lockdown adalah salah satu cara yang dapat ditempuh oleh Pemerintah. Kebijakan ini diharapkan mampu mengatasi dan memutus segala permasalahan yang berhubungan dengan COVID- 19, namun kegiatan tersebut akan memberikan dampak yang sangat besar di segala faktor khususnya faktor ekonomi suatu daerah. Dikarenakan resiko tersebut, pengambilan suatu keputusan yang tepat merupakan suatu kewajiban yang harus dilaksanakan oleh pemerintah.

Timbul beberapa pertanyaan, bagaimana pemerintah mengambil keputusan dengan akurat? Salah satu jawabannya adalah menggunakan SPK (Sistem Pendukung Keputusan) [1]. Dalam Sistem Pendukung Keputusan ini 
Metode Topsis adalah metode yang kami gunakan untuk melakukan perhitungan terhadap kasus ini sesuai dengan alternative dan kriteria yang nantinya menghasilkan suatu hasil yang dapat membantu Pemerintah dalam mengambil keputusan.

Sistem Pendukung Keputusan yaitu sebuah sistem berbasis komputer yang adaptif, fleksibel dan interaktif yang digunakan untuk memecahkan masalah-masalah tidak terstruktur sehingga mengkatkan nilai keputusan yang diambil [2].

\section{METODOLOGI}

\section{A. Sistem Pendukung Keputusan}

DSS atau Sistem Pendukung Keputusan merupakan suatu sistem yang dapat melakukan pemecahan masalah baik terstruktur maupun tidak. Sistem ini sering digunakan untuk membantu pengambilan keputusan dalam situasi semi terstruktur dan situasi yang tidak terstruktur. Moore dan Chang [3] berpendapat, SPK atau Dss ini dapat digambarkan sebagai suatu sistem yang memiliki kemampuan untuk mendukung analisis ad hoc data, pemodelan keputusan, berorientasi keputusan, orientasi perencanaan masa depan, dan digunakan pada saat- saat tidak biasa. SPK juga bertujuan untuk menyediakan dan memberikan informasi kepada konsumen untuk melakukan pengambilan keputusan dengan lebih baik.

\section{B. Pembatasan Sosial Berskala Besar}

PSBB adalah Pembatasan Sosial Berskala Besar, suatu peraturan yang diterbitkan oleh pemerintah demi mengamankan suatu wilayah dari suatu wabah atau penyakit. ditahun ini pandemi covid-19 merupakan suatu virus yang menyebabkan pemerintah mengambil langkah ini. Psbb suatu wilayah harus dilakukan secara hati hati dan akurat, karena efek dari psbb akan sangat besar terutama pada sektor ekonomi suatu wilayah

\section{Metode Topsis}

1. Konsep Dasar

TOPSIS merupakan suatu metode pengambilan keputusan multikriteria yang pertama kali diperkenalkan oleh [4]. TOPSIS menganut prinsip bahwa alternatif yang terpilih harus mempunyai jarak terdekat dari solusi ideal positif dan jarak terpanjang (terjauh) dari solusi ideal negatif dari sudut pandang geometris dengan menggunakan suatu jarak Euclidean (jarak antara kedua titik) untuk menentukan besaran kedekatan relatif dari suatu alternatif dengan solusi yang optimal. Solusi ideal positif diartikan sebagai jumlah dari seluruh nilai terbaik yang dicapai untuk setiap atribut, sedangkan solusi negatif-ideal terdiri dari seluruh nilai terburuk yang dicapai untuk setiap atribut. TOPSIS juga mempertimbangkan keduanya, antara jarak solusi ideal positif dan jarak solusi ideal negatif dengan mengambil kedekatan relatif terhadap solusi ideal positif.

Berdasarkan perbandingan yang diambil dari jarak relatifnya, susunan prioritas alternatif dapat dicapai. Metode ini digunakan untuk menyelesaikan suatu pengambilan keputusan secara praktis. beberapa hal yang membuat Topsis populer ialah konsepnya, efisien dan memiliki kemampuan mengukur kinerja relatif dari alternatif alternatif keputusan.

2. Kegunaan Topsis

Metode ini digunakan untuk menyelesaikan pengambilan keputusan secara praktis. Pengambilan keputusan untuk kota yang harus menerapkan pembatasan sosisal berskala besar yang di sebabkan wabah corona ini menggunakan kriteria - kriteria dalam penilaiannya, kriteria tersebut adalah jumlah ODP, jumlah PDP, jumlah warga yang meninggal, banyak penduduk, luas daerah, warga yang sudah sembuh.

3. Kelebihan Topsis

- Konsepnya yang sederhana dan mudah dipahami.

- Komputasinya efisien.

- Memiliki kemampuan yang jarang dimiliki metode lain contohnya mengukur kinerja relatif dari alternatif-alternatif keputusan dalam bentuk yang sederhana. Dapat digunakan sebagai metode pengambil keputusan yang lebih cepat

4. Prosedure Topsis

Tahapan Dalam Metode TOPSIS :

a) Membuat Ranking Tiap Alternatif

$$
r_{i j}=\frac{x_{i j}}{\sqrt{\sum_{i=1}^{m} x_{i j}^{2}}}
$$

b) Membuat Keputusan Ternormalisasi ( R )

c) Membuat Keputusan Ternormalisasi Terbobot (Y)

$$
\text { Yij = wi riji }
$$

d) Membuat Solusi Ideal Positif ( $\mathrm{A}+$ ) dan Negatif ( A- ) Solusi Ideal Positif (A+)

$$
A^{+}=\left(y_{1}^{+}, y_{2}^{+}, \ldots, y_{n}^{+}\right)^{\prime}
$$

Solusi Ideal Negatif (A-)

$$
A^{-}=\left(y_{1}^{-}, y_{2}, \ldots, y_{n}^{-}\right)
$$

Keterangan :

$\mathrm{Y}+\mathrm{j}$ adalah :

- Max yij, jika j adalah atribut keuntungan

- Min yij, jika j adalah atribut biaya

Y-j adalah :

- Max yij, jika j adalah atribut keuntungan

- Min yij, jika j adalah atribut biaya

Dapat digunakan sebagai metode pengambil keputusan yang lebih cepat.

e) Membuat Jarak Solusi Ideal Positif dan Negatif ( D)

Jarak Solusi Ideal Positif (D+) 


$$
D_{i}^{+}=\sqrt{\sum_{j=1}^{n}\left(y_{i}^{+}-y_{i j}\right)^{2}} ; \mathrm{i}=1,2, \ldots, \mathrm{m}
$$

Jarak Solusi Ideal Negatif (D-)

$$
D_{i}^{-}=\sqrt{\sum_{j=1}^{n}\left(y_{i j}-y_{i}^{-}\right)^{2}} ; \mathrm{i}=1,2, \ldots, \mathrm{m}
$$

f) Membuat Nilai Preverensi (V)

Nilai preferensi akan diberikan pada setiap alternatif (Vi) sebagai :

$$
V_{i}=\frac{D_{i}^{-}}{D_{i}^{-}+D_{i}^{+}}
$$

Nilai Vi yang lebih besar nilainya menunjukkan bahwa alternatif Ai lebih dipilih.

\section{HASIL DAN PEMBAHASAN}

Berikut adalah perhitungan dengan menggunakan metode TOPSIS :

a) Penilaian tiap kriteria

Kriteria tersebut adalah jumlah ODP, jumlah PDP, jumlah warga yang meninggal, banyak penduduk, luas daerah, warga yang sudah sembuh.

\begin{tabular}{|c|c|}
\hline \multicolumn{2}{|l|}{ Alternatif } \\
\hline A1 & MALANG \\
\hline A2 & SURABAYA \\
\hline A3 & SIDOARJO \\
\hline A4 & GRESIK \\
\hline
\end{tabular}

b) Pembobotan Kriteria

\begin{tabular}{|c|c|}
\hline $\begin{array}{l}\text { Ranking kecocokan setiap } \\
\text { alternatif pada setiap }\end{array}$ & $\begin{array}{l}\text { Ranking kecocokan setiap } \\
\text { alternatif pada setiap }\end{array}$ \\
\hline "l = sangat tinggi & 'l = sangat rendah \\
\hline $2=$ finggi & '2 = rendah \\
\hline $3=$ sedang & $3=$ sedang \\
\hline $4=$ rendah & '4 = tinggi \\
\hline $5=$ sangat rendah & -5 = sangat tinggi \\
\hline cost & Benefit \\
\hline
\end{tabular}

\begin{tabular}{|c|c|c|c|}
\hline \multicolumn{2}{|c|}{ Kriteria } & Bobot & \\
\hline C1 & ODP & 10 & cost \\
\hline C2 & PDP & 20 & cost \\
\hline C3 & MENGGGAL & 25 & cost \\
\hline C4 & SEMBUUH & 25 & benefit \\
\hline C5 & BANYARPENOUDUK & 10 & cost \\
\hline C6 & LUASDAERAH & 10 & benefit \\
\hline
\end{tabular}

c) Rangking kecocokan d)

Matriks Keputusan
\begin{tabular}{|c|c|c|c|c|c|c|}
\hline \multirow{2}{*}{ Alembitifi } & \multicolumn{7}{|c|}{ Kinteria } \\
\cline { 2 - 7 } & C & Q & B & C & 65 & 66 \\
\hline Al & 4 & 5 & 3 & 3 & 4 & 4 \\
\hline A2 & 5 & 5 & 3 & 4 & 5 & 4 \\
\hline A3 & 4 & 4 & 4 & 3 & 5 & 3 \\
\hline A & 3 & 3 & 3 & 3 & 4 & 4 \\
\hline
\end{tabular}

e) Matriks Ternormalisasi

$x 1=\sqrt{4^{2}+5^{2}+4^{2}+3^{2}}$

$=8,124$

$$
\begin{aligned}
& r 11=\frac{4}{8,124} \\
& =0,492 \\
& r 21=\frac{5}{8,124} \\
& =0,615 \\
& x 2=\sqrt{5^{2}+5^{2}+4^{2}+3^{2}} \\
& =8,660 \\
& r 12=\frac{5}{8,660} \\
& =0,577 \\
& r 22=\frac{5}{8,660} \\
& =0,577
\end{aligned}
$$

\begin{tabular}{|c|c|c|c|c|c|c|}
\hline \multirow{2}{*}{ Altematifi } & \multicolumn{6}{|c|}{ Kiteria } \\
\hline & C1 & 0. & $\mathrm{C}$ & CA & 15 & $\mathrm{Cb}_{6}$ \\
\hline AI & 4,924 & 11547 & 11,437 & 11,437 & 4,417 & 5,298 \\
\hline Al & 6,155 & 11,547 & 11,437 & 15,250 & 5,522 & 5,298 \\
\hline A3 & 4,924 & 9,238 & 15,550 & 11,437 & $5,522$. & 3,974 \\
\hline A & 3,693 & 6,928 & 11,437 & 11,437 & 4,417 & 5,298 \\
\hline
\end{tabular}

\begin{tabular}{|c|c|c|c|c|c|c|}
\hline $\mathrm{Ht}$ & 6,155 & 11,547 & 15,260 & 15260 & 5,5212 & 5,988 \\
\hline A. & 3,5929 & 6,988 & $11,4,97$ & 11,437 & 4,47 & 3.974 \\
\hline
\end{tabular}

Demikian sampai di dapat hasil seperti tabel di bawah ini :

\begin{tabular}{|c|c|c|c|c|c|c|}
\hline \multirow{2}{*}{ Alematif } & \multicolumn{6}{|c|}{ Kriteria } \\
\cline { 2 - 7 } & $C 1$ & $C$ & $C 3$ & $C 4$ & $C 5$ & $C 6$ \\
\hline A1 & 0,492 & 0,577 & 0,57 & 0,457 & 0,42 & 0,530 \\
\hline A2 & 0,615 & 0,577 & 0,457 & 0,610 & 0,552 & 0,530 \\
\hline A3 & 0,492 & 0,462 & 0,610 & 0,457 & 0,552 & 0,397 \\
\hline A4 & 0,369 & 0,346 & 0,457 & 0,457 & 0,42 & 0,530 \\
\hline
\end{tabular}

f) Bobot Normalisasi

Hasil dari Matriks Keputusan Ternormalisasi X Botot $=$ Tabel di bawah ini :

g) Solusi Ideal Positif dan Negatif

h) Jarak antara nilai terbobot setiap alternative terhadap solusi ideal positif dan negative Positif :

D1+ =

$(4,924-6,155)^{2}+(11,547-11,547)^{2}+$

$(11,437-15,250)^{2}+(11,437-15,250)^{2}+(4,417-5,522)^{2}+(5,298-5,298)^{2}$

Negatif :

D1- = 
$\sqrt{(4,924-3,693)^{2}+(11,547-6,928)^{2}+}$

Demikian seterusnya sampai dapat hasil seperti tabel di bawah ini :

\begin{tabular}{|c|c|c|}
\hline Alternatif & D+ & D- \\
\hline A1 & 5,640 & 4,960 \\
\hline A2 & 3,812 & 6,701 \\
\hline A3 & 4,810 & 4,754 \\
\hline A4 & 7,595 & 1,325 \\
\hline
\end{tabular}

i) Kedekatan setiap alternative terhadap solusi ideal :

$$
\begin{aligned}
& \mathrm{V} 1=\frac{4,960}{4,960+5,640}=0,468 \\
& \mathrm{~V} 2=\frac{6,701}{6,701+3,812}=0,637 \\
& \mathrm{~V} 3=\frac{4,754}{4,754+4,810}=0,497 \\
& \mathrm{~V} 4=\frac{1,325}{1,325+7,595}=0,148
\end{aligned}
$$

\begin{tabular}{|c|c|c|} 
Alternatif & Nilai & Rangking \\
\hline A1 & 0,468 & 3 \\
\hline A2 & 0,637 & 1 \\
\hline A3 & 0,497 & 2 \\
\hline A4 & 0,148 & 4 \\
\hline
\end{tabular}

\section{A. Tampilan}

a) Tampilan Awal Aplikasi

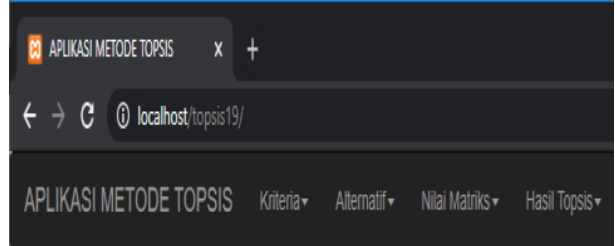

b) Tampilan form saat kita menambahkan kriteria

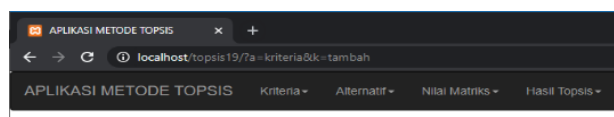

Kriteria

Tambah Kriteria

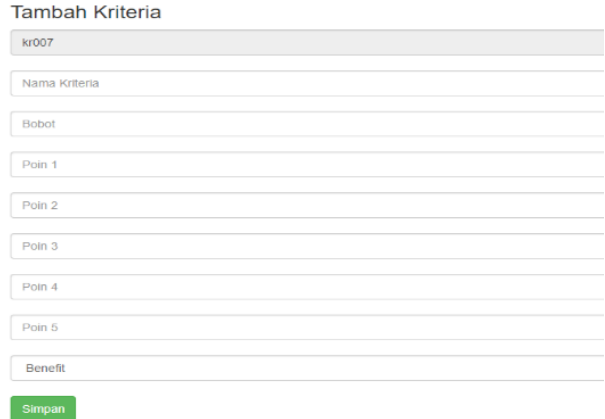

c) Setelah kita menambahkan Kriteria maka data tersebut akan di simpan di "Data Kriteria". Di dalam "Data Kriteria" ini terdapat 2 fitur yaitu :

- Update : Digunakan untuk mengganti data kriteria yang sudah tersimpan.

- Delete : Digunakan untuk menghapus datayang salah
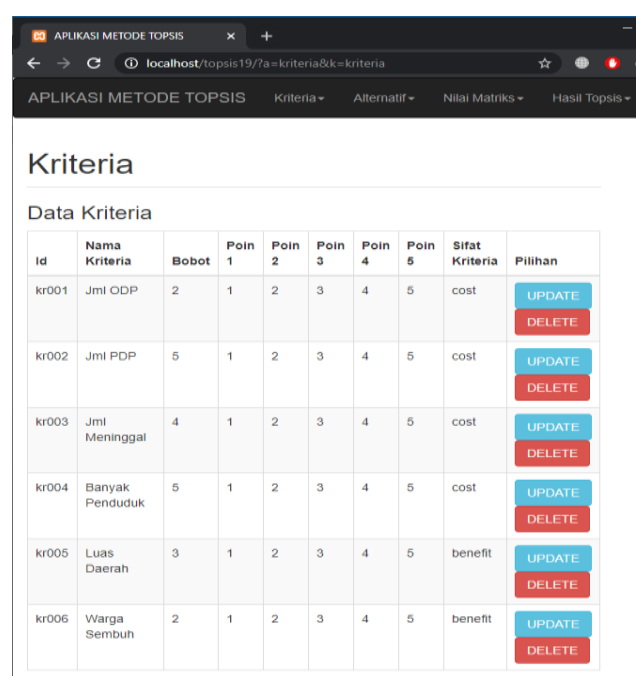
d) Tampilan form saat kita menambahkan Alternatif baru

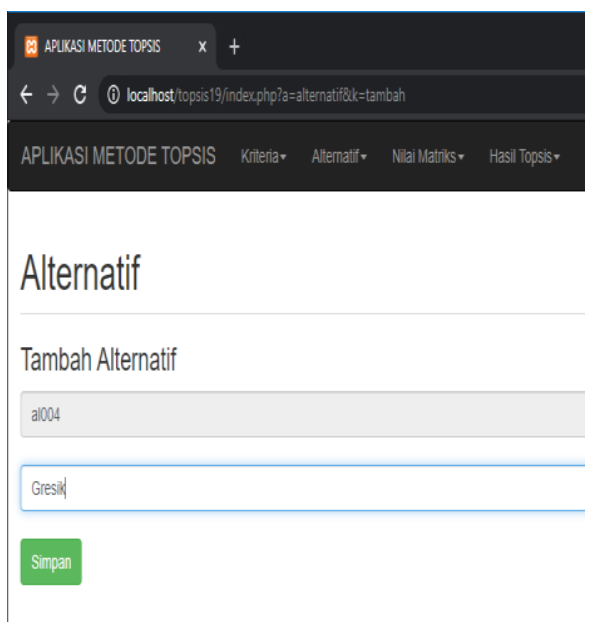

e) Setelah kita menambahkan Kriteria maka data tersebut akan di simpan di "Data Alternatif". Di dalam "Data Alternatif" ini terdapat 2 fitur yaitu :

- Update : Digunakan untuk mengganti data alternatif yang sudah tersimpan.

- Delete : Digunakan untuk menghapus data yang tidak digunakan.
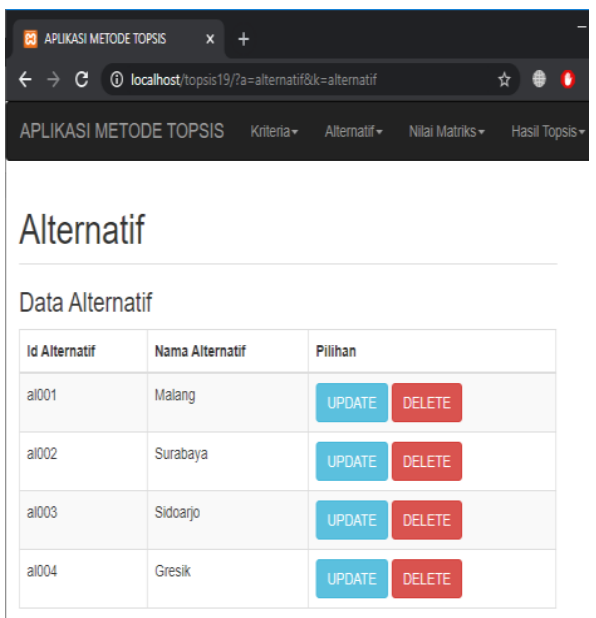

f) Di Tampilan "Nilai Matriks" ini kita dapat mengisi:

- Jumlah ODP

- Jumlah PDP

- Jumlah Meninggal

- Banyak Penduduk

- Luas Daerah

- Warga Sembuh

Di masing - masing Kota yang telah terdaftar melakukan Pembatasan Sosial Berskala Besar Yang Di Sebabkan Wabah Corona.

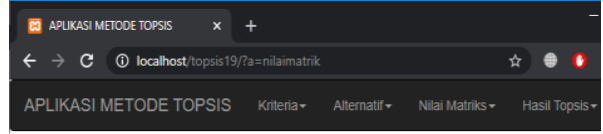

Nilai Matriks

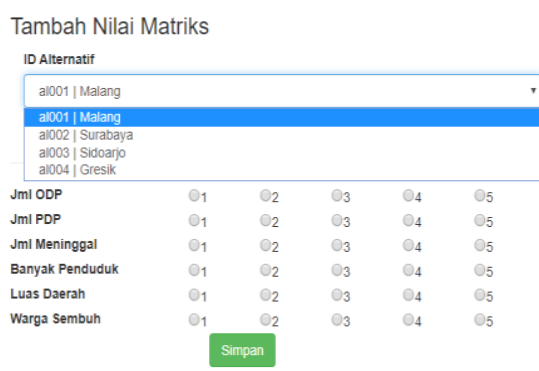

g) Setelah kita menambahkan Data di setiap Kota, maka data akan di tampilkan di halaman "Hasil Topsis Nilai Matriks"

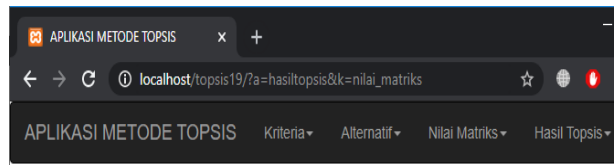

\section{Hasil Topsis}

\begin{tabular}{|c|c|c|c|c|c|c|c|}
\hline \multirow[b]{2}{*}{ № } & \multirow[b]{2}{*}{ Nama } & \multicolumn{6}{|c|}{ Kriteria } \\
\hline & & c1 & C2 & $\mathrm{cs}$ & $\mathrm{C4}$ & C5 & $c 6$ \\
\hline 1 & Malang & 2 & 3 & 4 & 2 & 4 & 5 \\
\hline 2 & Surabaya & 5 & 3 & 1 & 3 & 2 & 4 \\
\hline 3 & Sidoarjo & 2 & 2 & 3 & 1 & 5 & 4 \\
\hline 4 & Gresik & 1 & 4 & 3 & 4 & 5 & 5 \\
\hline
\end{tabular}

h) Tampilan saat nilai matriks telah di normalisasikan

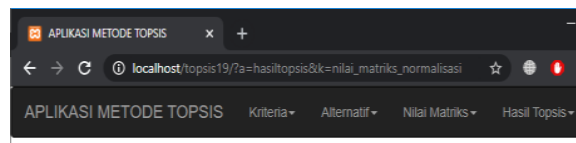

Hasil Topsis

Nilai Matriks Ternormalisasi




i) Kemudian kita mencari Bobot Ternormalisasi
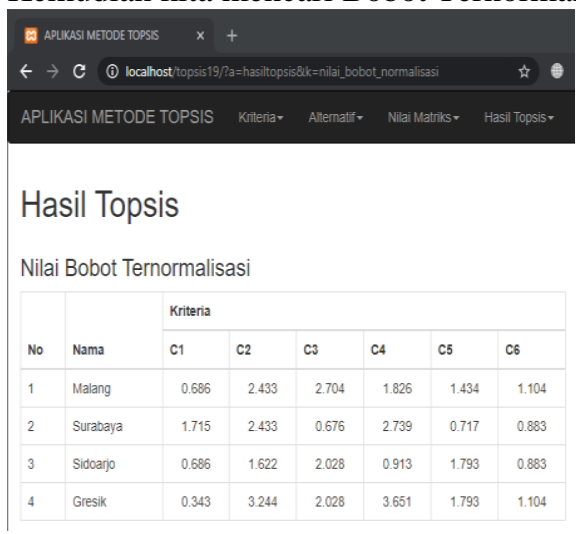

j) Kemudian kita mencari Matriks Ideal Positif dan Matriks Ideal Negatif

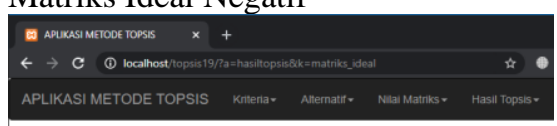

Hasil Topsis

Matriks Ideal Positif $\left(\mathrm{A}^{+}\right)$

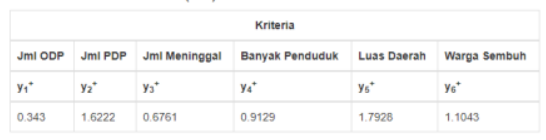

Matriks Ideal Negatif $\left(A^{-}\right)$



k) Kemudian kita mencari Jarak Solusi Ideal Positif dan Jarak Solusi Ideal Negatif


1) Kemudian di Nilai Preferensi ini kita dapat menentukan Kota yang akan melakukan Pembatasan Berskala Besar dengan nilai yang tertinggi

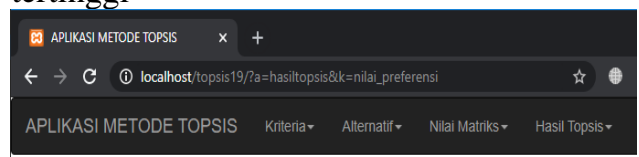

\begin{tabular}{|c|c|c|c|}
\hline Nilai Prefere & & & \\
\hline Nomor & Nama & & $v_{i}$ \\
\hline 1 & Gresik & 0.3525 & \\
\hline 2 & Surabaya & 0.4709 & \\
\hline 3 & Malang & 0.4948 & \\
\hline 4 & Sidoario & 0.717 & \\
\hline
\end{tabular}

\section{KESIMPULAN}

Dari hasil implementasi dan uji coba aplikasi Sistem Pendukung Keputusan Pemilihan Kota Yang Harus Menerapkan Pembatasan Sosisal Berskala Besar Yang Di Sebabkan Wabah Corona Menggunakan Metode TOPSIS maka dapat dibuat kesimpulan sebagai berikut :

- Metode TOPSIS dapat memberikan rekomendasi untuk Pemilihan Kota Yang Harus Menerapkan Pembatasan Sosisal Berskala Besar berdasarkan beberapa kriteria.

- Hasil pengujian sistem ini dapat membantu Pemerintah dalam mengambil keputusan Pemilihan Kota Yang Harus Menerapkan Pembatasan Sosisal Berskala Besar secara tepat.

- Berdasarkan uji coba yang telah dilakukan menghasilkan Kota Sidoarjo sebagai Kota yang harus melakukan PSBB.

\section{DAFTAR PUSTAKA}

[1] Ariansyah. (2016). Perencanaan Sistem Pendukung Keputusan Beasiswa Mahasiswa Di Sekolah Tinggi Manajemen Informatika Dan Komputer Prabumulih Dengan Fuzzy Multiple Attribute Decision Making ( Fmadm ). Jusim, 1(1), 1-7.

[2] Rianto. 2008. Sistem pendukung keputusan penentuan keluarga miskin untuk prioritas penerima bantuan menggunakan metode analytic hierarchy process :: Studi kasus Pedukuhan Bulu RT07, Trimulyo, Jetis, Bantul. Yogyakarta : Universitas Gadja Mada

[3] Jasri, D. Siregar and R. Rahim, "Decision Support System Best Employee Assessments with Technique for Order of Preference by Similarity to Ideal Solution," INTERNATIONAL JOURNAL OF RECENT TRENDS IN ENGINEERING \& RESEARCH, vol. 3, no. 3, pp. 6-17, 2017.

[4] K. SHAHROUDI and S. S. TONEKABONI, "APPLICATION OF TOPSIS METHOD TO SUPPLIER SELECTION IN IRAN AUTO SUPPLY CHAIN," Journal of Global Strategic Management, vol. 6, no. 2, pp. 123-131, 2012.

[5] Srikrishna S1, S. Reddy. A and V. S, "A New Car Selection in the Market using TOPSIS Technique," International Journal of Engineering Research and General Science, vol. 2, no. 4, pp. 177181,2014

[6] Kurniawan, Helmi. 2015. Sistem Pendukung Keputusan Penilaian Kinerja Karyawan Menggunakan Metode Topsis Berbasis Web Pada CV. Surya Network Indonesia.Bali: KNS \& I 
[7] Agung, H., \& Ricky, R. (2016). Aplikasi Sistem Pendukung Keputusan Untuk Pemilihan Siswa Teladan Menggunakan Metode Topsis. Jurnal Ilmiah FIFO, 8(2), 112. https://doi.org/10.22441/fifo.v8i2.1306

[8] Busthomy, A., Sultoni \& Hariyanto, R., 2016. Sistem Pendukung Keputusan Untuk Pemilihan Objek Wisata Di Kabupaten Pasuruan Dengan Menggunakan Metode Fuzzy. JIMP - Jurnal Informatika Merdeka Pasuruan, 2(1), pp. 33-56.

[9] Salahudin, M., Astuti, I. F. \& Kridalaksana, A. H., 2016. Sistem Pendukung Keputusan Berbasis Website Untuk Pemilihan Destinasi Pariwisata Kalimantan Timur Dengan Metode Elimination And Choice Expressing Reality (ELECTRE). Prosiding Seminar Ilmu Komputer dan Teknologi Informasi, Gunung Kelua Samarinda, Kalimantan Timur

[10] Marsono, Boy, A. F. \& Dari, W., 2015. Sistem Pendukung Keputusan Pemilihan Menu Makanan pada Penderita Obesitas dengan menggunakan Metode Topsis. Ilmiah Saintikom (Sains dan Komputer), 14(3), pp. 197-210.

[11] Mihuandayani, Ridho, M. Z. \& Widyastuti, D. A., 2016. Perancangan Sistem Pendukung Keputusan Untuk Pemilihan Objek Wisata Di Gunungkidul Dengan Algoritma Forward Chaining. Yogyakarta, s.n., pp. 133-138.

[12] Fitriana, A. N., Harliana \& Handaru, 2015. Sistem Pendukung Keputusan Untuk Menentukan Prestasi Akademik Siswa dengan Metode TOPSIS. Citec Journal, Februari, Volume 2, p. 156 http://ojs.amikom.ac.id/index.php/citec/article/download/371/351

[13] Titin Pujiani. (2015). Sistem Pendukung Keputusan Pemberian Pinjaman Koperasi Dengan Metode Technique For Order Preference By Similarity To Ideal Solution (Study Kasus: KPN Kesra Dinas Koperasi, UKM Deli Serdang) Volume : V, Nomor : 3 , Pebruari 2015 Majalah Ilmiah Informasi dan Teknologi Ilmiah (INTI) ISSN : 2339-210X.

[14] H. Slamet, R. Irviani, and Kasmi, "Sistem Pendukung Keputusan Pemilihan Guru Teladan MA Al Mubarok Batu Raja Menggunakan Metode Topsis," J. TAM (Technology Accept. Model., vol. 6, pp. $1-8,2016$.

[15] Ilmadi and D. N. Muskananfola, "SISTEM PENGAMBILAN KEPUTUSAN DALAM PEMILIHAN MERK SMARTPHONE ANDROID TERBAIK DIKALANGAN MAHASISWA UNIVERSITAS PAMULANG DENGAN MENGGUNAKAN METODE TOPSIS,” J. Sains dan Mat. Unpam, vol. 2, no. 1, pp. $58-75,2019$ 